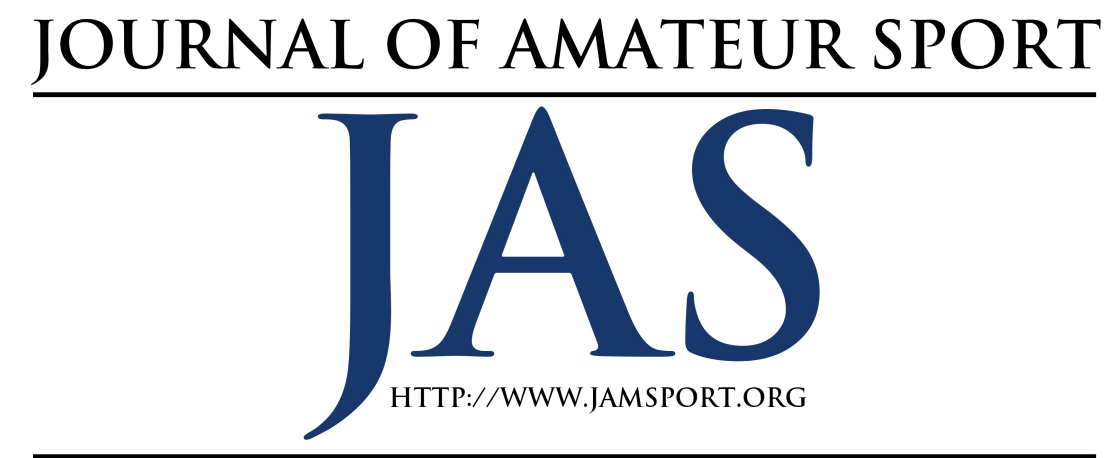

\title{
A Longitudinal Study of Team-Fan Role Identity on Self-Reported Attendance Behavior and Future Intentions
}

\author{
Galen T. Trail ${ }^{1}$ \\ Don Lee ${ }^{3}$ \\ ${ }^{1}$ Seattle University \\ ${ }^{2}$ Iowa State University \\ ${ }^{3}$ University of Houston
}

Dean F. Anderson ${ }^{2}$

\begin{abstract}
Attendance at college sporting events generates billions of dollars annually for athletics departments at the college level in the United States. Based on Identity Theory and prior research, we developed and tested two models that were successful in predicting actual attendance, attendance intentions (conative loyalty), and support for the team across time. Respondents $(\mathrm{N}=165 ; 60 \%$ female, 95\% Caucasian) filled out three surveys across the year. In Model A (RMSEA $=.066, x^{2} / d f=50.02 / 29=$ 1.73), prior season attendance, number of games intending to attend, and preseason team-fan role identity (Time 1) explained $63 \%$ of self-reported attendance behavior (Time 2). Those variables and postseason role identity (Time 2) explained $48.5 \%$ of attendance intentions (Time 3; Model A) and $43 \%$ of supporting the team in the future (Time 3; Model B, RMSEA $\left.=.060, x^{2} / d f=46.16 / 29=1.59\right)$. Sports marketers need to take into account both the impact of role identity as a fan of the team and attendance intentions, not just prior attendance behavior, when predicting future attendance behavior and support for the team.
\end{abstract}

$\mathrm{I}$

$\mathrm{n}$ the United States, attendance for the NCAA (National Collegiate Athletic Association) football teams is fairly high across the Big 5 conferences, but not impressive in other divisions. Across all NCAA divisions, it seems to have plateaued at around 50 million fans per year (Trail \& James, 2015). In the 2015 season, The Ohio State University averaged over 107,000 attendees per game (NCAA, 2016) and generated over $\$ 30$ million (U.S.) from ticket sales for the season, showing how 
important attendance and ticket sales are to athletics departments. However, at some schools, attendance numbers are critical not for revenue as much as for the importance of maintaining classification status (i.e., not being relegated to a lower division). If Football Bowl Subdivision schools do not average at least 15,000 on a rolling two-year period they can lose Division I membership (Bowl Subdivision Membership, 2016), which in turn can cost those schools shared revenues from Division I status.

This gives some evidence that one of the most difficult aspects of sport consumption behavior to predict may be attendance. Typically research has either tried to predict attendance intentions (Bodet \& Bernache-Assolant, 2011; Gray \& WertGray, 2012; Harrolle, Trail, Rodríguez, \& Jordan, 2010; Matsuoka, Chelladurai, \& Harada, 2003; Shapiro, Ridinger, \& Trail, 2013; Trail, Anderson, \& Fink, 2005; Trail, Fink, \& Anderson; 2003; Wang, Zhang, \& Tsuji, 2011; Wu, Tsai, \& Hung, 2012; Yoshida, Gordon, Nakazawa, \& Biscaia, 2014;) or has inappropriately measured past attendance and attempted to 'predict' it with measures taken afterwards (Bee \& Havitz, 2010; Heere et al., 2011; Kwon, Trail, \& Anderson, 2005; Laverie \& Arnett, 2000). In addition, there have been economic models that attempted to predict attendance with limited success as well (Baade $\&$ Tiehen, 1990; Greenstein \& Marcum, 1981).

Furthermore, all of the above studies were cross-sectional studies (i.e., the data was collected only at one time). Recently though, Yoshida, Heere, and Gordon (2015) and McDonald, Karg, and Leckie (2014) have done what the previous research did not, and that is to extend these crosssectional models to longitudinal models, collecting attendance behavior data (Yoshida et al., 2015) or season ticket renewal data (McDonald et al., 2014) several months after collecting attitudinal data. These researchers have advanced sport consumer behavior research with their models by collecting and testing data over time.

Building on their work, and the foundation of those that have come before, we propose and evaluate a model of selfreported attendance behavior. Extending the prior research, we collected attendance behavior for the previous season and collected attendance intentions for the current season (Time 1: Preseason). We then collected self-reported attendance after the current season ended (Time 2: Postseason) and finally attendance intentions at the end of the year (Time 3: End-of- Year). However, as Oliver (1999) has argued, it is not sufficient to assume that past behavior is the only, or best, predictor of future behavior. Cognitive measures need to be included as per Yoshida et al. (2015). Thus, we collected self-reported attendance data and a cognitive measure of role identity (fan of the team) data across the different times to determine the contributions of each as predictors.

Therefore, considering that attendance at college sporting events generates billions 
of dollars annually for athletics departments at the college level in the United States alone (Hobson \& Rich, 2015), and generates shared revenues for smaller schools that maintain sufficient attendance numbers to keep Division I status, the purpose of this study was to develop and test a model (Model A, Figure 1) that could be successful in predicting actual attendance (behavioral loyalty) and attendance intentions (conative loyalty) across time. However, attendance intentions are not the only potential measure of future loyalty. Thus, we also examined a similar model (Model B, Figure 1) that used a general measure of supporting the team in the future to determine if general support and intention to attend games are substantially different. We used identity theory to create the framework for both Model A and Model B. In Model A, we hypothesized that prior season attendance (a measure of behavioral loyalty) will impact preseason cognitive role identity (fan of the team), the number of games intending to attend (conative loyalty), and actual self-reported attendance (behavioral loyalty again, measured at the end of the season). In addition, we hypothesized that attendance behavior will predict postseason role identity and the likelihood of future attendance. Model B is the same as Model A except that rather than predicting end-ofthe-year attendance intentions we have substituted a more general measure of intention to support the team in the future, rather than attending future games.

\section{Theoretical Framework}

A primary tenet of identity theory is that people have role identities that are guided by past behavior and predict future behavior (Ervin \& Stryker, 2001). People have many role identities (e.g., mother, daughter, employee, and fan of a specific team). The specific identity is a set of beliefs about the importance of that role to the individual, e.g., 'I am an Ohio State fan', or 'Being a Buckeye fan is very important to me'.

Identity theory differs from social identity theory in a significant way in that social identity theory specifies that "a social identity is a person's knowledge that he or she belongs to a group" (Stets \& Burke, 2000, p. 225). As Trail and James (2015) noted, a social identity is an "identification with a collectivity or social category and (is) focused on category-based identities (e.g., Black or white, Christian or Muslim)" (p. 58), whereas an identity within identity theory is a role-based identity, such as teacher, mother, daughter, etc. Trail and James (2015) suggested that the role of sport fan can be either role-based or category-based. Not surprisingly, both identity theory and social identity theory have been used to explain why people are fans and fandom in general.

However, the way that role-based fandom should be measured versus how a category-based fandom should be measured, should be very different. The former should focus on cognitions about how important the role of fan of the team is to the individual, irrespective of any other fan or 
anyone else. It is the importance and salience of the role that creates an identity standard (Ervin \& Stryker, 2001). On the other hand, a category-based measure of fandom should focus on the social interaction with others in the same category, that is, other fans of the same ilk. Relative to the latter, Mael and Ashforth (1992) suggested, "the individual defines him or herself in terms of the organization(s) of which he or she is a member" (p. 104), or referent to fans, in terms of the community of fans of which he or she is a member. Heere et al. (2011) extended this idea and suggested several areas including the sense of interdependence with the group and interconnection with the group. In addition, in Yoshida et al. (2015), they included the idea of fan community or identifying with other people who follow the team. These latter concepts are obviously considerably different from the idea of role identity, which represents how important being a fan of a particular team is to that individual.

Prior research has looked at, and created measurement scales for both rolebased fandom and category-based fandom, and has called both "team identification," which is probably not correct. For example, the Team Identification Index (TII; Fink, Trail, \& Anderson, 2002; Trail \& James, 2001) was supposedly created as a categorybased measure according to the description and definition that Trail and colleagues have applied to it (e.g., Trail, Anderson, \& Fink, 2000; Trail et al., 2003; Trail \& James, 2001). Trail et al. (2000) defined identification as "an orientation of the self in regard to other objects, including a person or group that results in feelings or sentiments of close attachment" (p. 165-166). This definition squarely puts the TII in the social identity theory framework. In addition, they quoted a variety of research from social identity theory in support of team identification and the TII. However, the items in the TII do not represent social identity theory or 'team identification'. There is no mention of being a part of a group of fans or comparison to an outgroup, which is also a key component of social identity theory. The items focus on the "importance of being a fan," considering oneself to be a "real fan of the team," and "experiencing a loss" if the person had to stop being a fan of the team (see Table 1 for full TII item wording). We suggest that the items in the TII are representative of the importance of a rolebased identity and not a category-based identify, and represent the ideas in identity theory much more closely than those in social identity theory. In our present research, we focus on identity theory and the importance of a team-fan role-based identity represented by the items in the TII. However, we would suggest that the label TII is also not accurate as it may not represent team identification, and thus possibly should be changed. Although, because the items in the TII represent the idea of a fan role identity, we will use previous research with the TII to support our proposed hypotheses and to measure team-fan role identity. 
Role identity and conative loyalty. Conative loyalty is the behavioral intention to repurchase, "a deeply held commitment to buy" the brand (Oliver, 1999, p. 35). However, Oliver noted that this is similar to any other good intention and may not be realized. This is distinct from Dick and Basu's (1994) conception of a conative disposition that includes switching costs, sunk costs, and expectations. Oliver's conative loyalty more closely reflects Dick and Basu's expectation aspect of conation, but Oliver's conative loyalty solely focuses on the intentions with no reference to costs. We focus more on Oliver's definition and the distinction that conative loyalty is intentions only.

As noted above, a primary tenet of identity theory is that people have role identities that predict how they will behave in the future (Ervin \& Stryker, 2001). In addition, Oliver (1997) indicated that cognitive loyalty would have an influence on conative loyalty. If we assume that team identification (role identity as a fan) is similar to cognitive loyalty, then the role identity would be related to conative loyalty. Similarly, Azjen and Madden (1986) in their Theory of Planned Behavior (TPB) suggested that attitudes lead to intentions. Although role identities are not attitudes, they are cognitions, because attitudes are comprised of cognitive and affective components, it is an easy supposition to suggest that cognitions such as role identities could easily lead to behavioral intentions. This is supported empirically by prior research.

Within sport consumer behavior literature, the importance of role identity as a fan of a particular team (called team identification when using the TII historically) has been shown to be related to behavioral intentions relative to a team (conative loyalty), explaining anywhere from $10.9 \%$ of the variance (Yoshida et al., 2014) to $25 \%$ of the variance (Wu et al., 2012; Yoshida et al., 2015). However, not all measures of conative loyalty were the same. For example, Trail et al. (2005) found that role identity (TII) was correlated $(r=.396)$ with conative loyalty (measured by four items: likelihood of attending future games, purchasing the team's merchandise, buying the team's clothing and supporting the team), whereas Yoshida et al. (2014) found that role identity (TII; $\beta=.33$ ) predicted the probability of purchase intention (3 items: attend another sporting event, buying additional products, and spending more than $50 \%$ of the fan's spectator sport budget on the team). Wu et al. (2012) explained $25 \%$ of repatronage intentions (attending games, watching games on TV, and purchasing merchandise) and Shapiro et al. (2013) found $19.4 \%$ shared variance in a single item of attendance intentions and role identity (TII). Based on these results, we propose the following hypothesis:

Hypothesis 1: Preseason role identity will have a positive effect on current attendance intentions. 
In addition, Gray and Wert-Gray (2012) separated conative loyalty into in-person attendance intentions, media-based consumption intentions, team-merchandise consumption intentions, and word-ofmouth communication intentions. Role identity (TII) explained 10\%, 11\%, 24\% and $38 \%$ of the variance in each respectively across four separate regression analyses. This shows that attendance intentions could possibly differ from the likelihood of supporting the team in the future, as it differs from other intentions. Further evidence of the potential difference between attendance intentions and supporting the team is reflected in Trail et al.'s (2005) research, which shows that the factor loading of "more likely to attend future games" ( $\beta=.507)$ on the Conative Loyalty factor substantially differs from the factor loading of "more likely to support the team" in the future $(\beta=.723)$ on the Conative Loyalty factor. Thus, we propose:

Hypothesis 2: Postseason role identity will have a positive effect on likelihood of attending future games and likelihood of supporting the team in the future, but will vary between the two.

Role identity and behavioral loyalty. In our model, we assumed that some level of behavioral loyalty probably existed considering we were looking at college sport. Identity Theory supports the premise that role identity as a fan of the team is based on prior experience (cf. Ervin \& Stryker, 2001), which creates role-based beliefs about the team. In addition, we were interested if preexisting behavioral loyalty (represented by past attendance) would have an impact on current role identity. Past attendance behavior has been shown to be related to role identity (TII). Kwon et al. (2005) found that past attendance behavior was correlated $(r=.49)$ with role identity and Laverie and Arnett (2000) reported a correlation of .45 between past behavior and identity salience (somewhat like role identity based on their measure of it). Based on this research, we propose two more hypotheses:

Hypothesis 3: Past attendance behavior will have a positive influence on preseason role identity.

Hypothesis 4: Current attendance behavior will have a positive influence on postseason role identity.

Although the above-mentioned authors showed that a relationship existed between past attendance behavior and role identity, until Yoshida et al.'s (2015) research no one had determined if current role identity (TII) predicted future attendance behavior in a longitudinal study. Yoshida et al. (2015) determined that role identity (TII) measured at the fifth game of the season (Time 1) was not significantly predictive of actual attendance behavior over the first half of the season (games $1-11 ; \beta=.17$, Time 2), nor the second half of the season (games $12-21 ; \beta=.08$; Time 3$)$. These results are rather surprising and do not support Yoshida et al.'s (2015) hypotheses. In attempt to explain why this might be the case, they suggested that the reason that previous research had found significant 
relationships between role identity (TII) and attendance behavior (where they hadn't) was probably due to using self-reported attendance data rather than team-tracked attendance data as they did. Although this is one possibility, they did not collect selfreported data in addition to team-reported attendance data, so were unable to compare the two, and thus could not substantiate their premise.

Identity theory indicates that this relationship should exist. Stryker and Burke (2000) suggested that role identity leads to behavior, but indicated that it could be mediated by cognitive comparison. Thus, even though Yoshida et al. (2015) were unable to establish a relationship between role identity and actual attendance behavior measured in the future within their SEM model, based on prior research showing that relationships between the two variables do exist, and that Yoshida et al. (2015) show a correlation between role identity (TII) at Time 1 and Attendance frequency at Time 2 (.38) and at Time 3 (.30), we propose a fifth hypothesis:

Hypothesis 5: Preseason role identity will predict self-reported season attendance measured at the end of the season.

Stability of role identity across time. Using Identity Theory, in a longitudinal study, Serpe (1987) proposed and showed role identities were stable across time for college age individuals. Within sport, the stability of role identity over time has not been examined before. However, categorybased team identification measures have been assessed over time and moderate stability has been found. Gau, Wann, and James (2010) found that team identification did have stability across a season as it was correlated at .58 from Time 1 to Time 2 . Similarly, Lock, Funk, Doyle, and McDonald (2014), in a more extensive study, tested a five-dimension measure of identification across time and found correlations ranging from .49 to .78 . Based on the above information, we propose a sixth hypothesis:

Hypothesis 6: Preseason role identity will be positively related to postseason role identity.

Past behavior to conative loyalty. According to Azjen (1991), in the Theory of Planned Behavior (TPB), past behavior typically predicts future behaviors or behavioral intentions and Smith et al. (2008) in an effort to improve the TPB, suggested that past behavior is often "the strongest predictor of self-reported intentions" ( $p$. 315). Similarly, Oliver (1999) in his loyalty theory, indicated that past experiences would eventually lead to conative loyalty.

Conative loyalty can include both intentions to attend games and intentions to support the team in general (Trail et al., 2005). In a study about college football games (U.S.), Shapiro et al. (2013) determined that the number of past games attended was correlated with attendance intentions $(r=.608)$ and intentions to purchase merchandise $(r=.224)$, but not meaningfully correlated with intentions to support sponsors of the team $(r=.167)$. The attendance measures were self-reported 
items asking how many games the respondent went to during the current season and how many they intended to go to during the next season. Bodet and Bernache-Assollant (2011) also found that number of past home games attended was correlated with intentions to attend the next game of the team $(r=.368)$. Zhang et al. (2003) found that the number of games attended in the prior season and to that point during the current season was related to the number of games intending to attend the rest of the season and the next season. Although as far as we can tell, no one has directly tested the relationship between past behavior and intentions to support the team, as noted above, intentions to attend games and intentions to support the team may differ (Gray \& Wert-Gray, 2012; Trail et al., 2005). Based on this information we formed Hypothesis 7:

Hypothesis 7: Prior attendance will have a positive influence on conative loyalty (intentions to attend games and support the team), but will impact likelibood of attending future games differently than likelihood of supporting the team in the future.

\section{Conative loyalty to behavioral} loyalty. Oliver (1999) suggested that conative loyalty precedes behavioral loyalty, but is not a perfect predictor as many barriers could constrain intentions from becoming actual behavior. Yoshida et al. (2015) are the only ones we know of that have tested this relationship over time on game attendance behavior. They found that behavioral intentions at Time 1 were significantly correlated $(r=.31)$ with team- reported attendance at Time 2 , but not at Time $3(r=.15)$. As noted above though, their behavioral intentions dimension measured three probabilities: "attending another sporting event of my team," "spending more than $50 \%$ of my sport consumption budget on my team," and making the "same choice" to attend the game again. The factor loading of the first item was low $(\beta=.54)$ indicating that it shared only $25 \%$ of the variance with the other two items. Because this item did not contribute much to the behavioral intention factor, it is highly likely that the item would have been differentially correlated with the attendance items than with the scale. Thus, we propose:

Hypothesis 8: Conative loyalty will have a positive impact on self-reported season attendance (measured in the future).

\section{Past behavior to present behavior.} Within Loyalty Theory, Oliver (1999) and Dick and Basu (1994) both imply that past behavior predicts future behavior, especially in terms of repatronage. As far as we can tell, the path from prior season attendance to actual current season attendance (measured across time) has not been tested, but Yoshida et al. (2015) did report a correlation between attendance frequency at Time 2 and at Time $3(r=.78)$ in a single season. Thus, we expect the two to be highly correlated.

Hypothesis 9: Prior season attendance will be positively correlated with current season attendance. 
Figure 1 depicts all of the paths and hypotheses across the two models. The similarities across the models are obvious, but this allows for comparison of the path coefficients and the explained variance in the dependent variables. This allows us to assess the predictive value of the preceding variables in the models on likelihood of future attendance versus likelihood of future support of the team, a much more general measure, but one that is often included in a conative loyalty measure (as noted above). If the results differ, then that indicates they should not be included together in the same measure of conative loyalty, even if they are relatively highly correlated.

\section{Method}

\section{Sampling Procedure}

Data were collected at the beginning of fall semester in late August just before the team's season began (Preseason), but after school started, from a convenience sample of 502 college students taking classes in the Department of Health and Human Performance at a large Mid-western university. The students filled out the paper and pencil survey during class time. The same group of students was emailed the second survey at the end of the fall semester in December after the team's season had ended (Postseason). The students emailed back their responses, which were matched by an identification number to the first survey. Of the original 502, 357 responded to the Postseason questionnaire, but due to missing items only 325 were useable. At the end of the second semester in late May (End-of-Year), we emailed the third survey to those who had completed both the first and second surveys and again matched responses using the identification number. Of the 325 that completed the second survey, 187 completed the third survey. However, we only had complete data on 165 matched responses across all three surveys on the variables included in this analysis. We checked for non-response bias by evaluating the differences on preseason Role Identity between the first 100 people to fill out the survey and the last 100 people to fill out the survey (out of the 502). The ANOVA indicated no significant differences $(\mathrm{F}(1,200)=0.37, \mathrm{p}=.848 ; M$ $($ Early $)=4.73, M$ (Late $)=4.77)$. We also tested those who filled out the survey at only at Time 1 (preseason) versus those who filled out survey at both Time 1 and Time 3 (End-of-Year). The ANOVA on Role Identity showed no significant differences $(\mathrm{F}(1,502)=1.46, \mathrm{p}=.227 ; M$ $($ Time 1$)=4.58, M($ Time 3$)=4.74$.

Incentives were offered to respondents who completed the survey. Respondents had the option to enter a drawing to win one of several prizes. The information collected for the drawings was kept separate from survey responses to maximize anonymity and confidentiality. The Human Subjects Board at the university approved the research. 


\section{Description of Sample}

The final sample of 165 was approximately $60 \%$ female, and almost 95\% Caucasian. The average age of the students was 20.5 years $(S D=2.6)$ when the study started and there was a distribution across the number of years in college $\left(1^{\text {st }}\right.$ year $=$ $18.6 \%, 2^{\text {nd }}$ year $=21.4 \%, 3^{\text {rd }}$ year $24.9 \%, 4^{\text {th }}$ year $=22.3 \%, 5^{\text {th }}$ year $($ or more $)=12.8 \%$ ). The average number of years being a fan of the university's football team was 7.7 (SD = 6.07). This was not surprising as most of the students were from the general vicinity in the state and it was a state university.

\section{Materials}

The Preseason questionnaire included the demographic items and three items from the Team Identification Index (TII; Trail et al. 2003; Trail \& James, 2001), which we used for a measure of role identity as a team fan, because the items within the TII focus on the importance of the role of being a fan of that particular team. The reliability of the TII has been shown across multiple data collections (Fink et al., 2002; James \& Trail, 2008; Kim \& Trail, 2010; Kim, Trail, \& Magnusen, 2013; Robinson et al., 2005; Shapiro et al., 2013). The items from the TII were measured on a 7-point Likert-type scale from 1 = Strongly Disagree to $7=$ Strongly Agree, with $4=$ Neutral. We also included one item measuring the number of home football games attended during the previous year, and one item measuring the number of home football games intending to attend during the upcoming season.

The Postseason questionnaire had the same items as the preseason questionnaire (TII). We also recorded the number of selfreported home football games attended during the season that just ended. The Endof-Year questionnaire had one item measuring likelihood of attending in the future and one item measuring the likelihood of supporting the team in the future.

\section{Results}

We used the RAMONA Structural Equation Modeling (SEM) technique, available in the SYSTAT 7.0 (1997) statistical package to test a CFA, with the three role-identity items measured at Time 1 and Time 2 . In addition, we included the single items measuring prior season attendance and number of games intending to attend at Time 1, self-reported game attendance at Time 2, and likelihood of attending future games and likelihood of supporting the team in the future at Time 3. Error terms of the role identity items were not correlated across time in the model even though others have done so because it typically artificially increases the fit of the model.

$\mathrm{Hu}$ and Bentler (1999) suggested that RMSEA values less than .060 indicated a close fitting model, $.061-.080$ indicated reasonable fit, $.081-.100$ indicated mediocre fit, and values $>.100$ were unacceptable. For the CFA, the RMSEA 
value was .065 , with a CI from .031 to.096, and the $\chi^{2} / d f=47.578 / 28=1.70$, indicating reasonable fit. The AVE values for the role identity items were .712 (Time 1) and .706 (Time 2 ) and the CR values were .88 (at both Time 1 and Time 2), indicating good construct reliability (Table 1). The correlations among the variables ranged from .380 to .817 (Table 2). The highest correlation was between the preand post-Role Identity as they were the same items measured across the two different times. These high correlations indicated good test-retest reliability. There was discriminant validity as all AVE values exceeded the squared correlations between any two variables (Table 2).

Both models fit the data well. For Model A, the RMSEA value was .066 and the $\chi^{2} / d f=50.02 / 29=1.73$, with no residuals greater than .1 , indicating reasonable to good fit. For Model B, the RMSEA value was .060 and the $\chi^{2} / d f=$ $46.16 / 29=1.59$, with no residuals greater than .1, indicating good fit. The path coefficients, and whether each individual hypothesis was supported or not, are reported in Table 3.

\section{Discussion}

The purpose of this study was to test two competing models primarily derived from identity theory, but to some extent influenced by the Theory of Planned Behavior and Loyalty Theory, that predicted attendance intentions (conative loyalty) and self-reported attendance behavior (behavioral loyalty) over time. Models A and $B$ differed from each other only by the ultimate dependent variable in the model. In Model A, we were trying to predict the likelihood of attending games during the following season, whereas in Model B we substituted a general conative loyalty measure: likelihood of supporting the team in the future. Our rationale for these different models was to determine whether likelihood of supporting the team was sufficiently distinct enough from likelihood of future attendance that both should not be included in the same conative loyalty measure as both frequently are (Harrolle et al., 2010; Trail et al., 2003; Trail et al., 2005). We will first discuss the models in general (with a few allusions to the specific hypotheses) and then discuss each hypothesis specifically.

Model Fit. Both models fit the data well. In Model A, prior season attendance, number of games intending to attend, and preseason Role Identity (importance of the role of being a fan of the team; all measured at Time 1) combined to explain slightly more than $63 \%$ of the variance in selfreported attendance behavior (Time 2). In addition, those variables and postseason Role Identity (Time 2) combined to explain $48.5 \%$ of likelihood of attending games during the following season (Time 3; Model A) and almost $43 \%$ of the variance in likelihood of supporting the team in the future (Time 3; Model B). 


\section{Attending Future Games vs.} Supporting the Team. The differences in variance explained between likelihood of attending future games and likelihood of supporting the team was small. In Model A, the amount of variance in likelihood of attending future games (Time 3) explained by the whole model was $48.5 \%$ and the primary predictor was postseason Role Identity $(\beta=.438 ; 19.1 \%)$ rather than selfreported attendance $(\beta=.370 ; 13.7 \%)$. Similarly, in Model B, the amount of variance in supporting the team in the future (Time 3) explained by the whole model was $42.9 \%$ and once again postseason Role Identity $(\boldsymbol{\beta}=.502)$ explained more variance $(25 \%)$ than selfreported attendance $(\beta=.243 ; 6 \%)$. This indicates that these two variables were distinct enough that they should be measured separately, even though they were highly correlated ( $r=.783$; Table 2$)$. This is similar to what Gray and Wert-Gray (2012) found when running separate regressions on attendance intentions, merchandise consumption intentions, media consumption intentions, and word-ofmouth intentions.

Support of Hypotheses. Now let us look at the specific hypotheses to determine whether they were supported or not. Although the path from preseason Role Identity (Time 1) to number of games intending to attend (Time 1) was significant (supporting H1), it explained only slightly more than $4 \%$ of the total variance in game attendance intentions, when all of the other variables were in the model. Interestingly though, postseason Role Identity (Time 2) explained $19 \%$ of the likelihood of attending future games (Time 3), supporting $\mathrm{H} 2$, when all of the other variables were in the model. Although some of the difference in variance explained could be due to how attendance intentions were measured in Time 1 (number of games) versus Time 3 (rating likelihood), the shared variances (squared bivariate correlations; Table 2) do not show such dramatic differences. The shared variance between preseason Role Identity and preseason intentions to attend was $22 \%$, whereas it was $27 \%$ between postseason Role Identity and future likelihood, indicating the impact of other factors in the model influenced the path coefficients. These results supported previous research (Bodet \& BernacheAssollant, 2011; Gray \& Wert-Gray, 2012; Matsuoka et al., 2003; Shapiro et al., 2013) and identity theory (Stryker \& Burke, 2000).

Not surprisingly, attendance had differential effects on Role Identity, depending on where the relationship existed in the model. In support of Hypothesis 3, prior season attendance explained 19\% of the variance in preseason Role Identity, but current season attendance only explained $4 \%$ of the variance in postseason Role Identity. The latter supported Hypothesis 4, but the variance was negligible. The differences were probably due to the path between preseason Role Identity and postseason Role Identity. Preseason Role Identity explained $55 \%$ of the variance in 
postseason Role Identity (supporting Hypothesis 6 and the research of Lock et al., 2014). This relationship could have subsumed some of the shared variance between preseason Role Identity and current season attendance, reducing the influence of the latter on postseason Role Identity.

Above, we noted that Hypothesis 5 was not supported because there was no significant relationship between preseason Role Identity and current attendance due to other variables in the model. This was primarily due to the substantial amount of variance explained in number of games intending to attend (Time 1) by prior season attendance (29\%) supporting Hypothesis 7 (and supporting Shapiro et al., 2013). It was also due to the amount of variance explained by number of games intending to attend (Time 1) in current season attendance (50\%; Time 2), supporting Hypothesis 8 and Yoshida et al.'s (2015) research. Furthermore, these path coefficients show that the relationship between prior season attendance (Time 1) and current season attendance (Time 2) was fully mediated mainly by number of games intending to attend (Time 1), but also to some small extent by preseason Role Identity. Due to these mediated relationships, Hypothesis 9 was not supported even though the correlation between prior attendance and current attendance was .581 (Table 2) similar to what Yoshida et al. (2015) found.
In sum, our results supported much of the prior research, but also provided considerably more information about the relationships between role identity and both conative and behavioral loyalty across time. However, the results from the models also created many questions as well. There are obviously many mediated relationships that have not been previously investigated and were not anticipated. For example, why would intentions almost fully mediate the relationship between prior attendance and current attendance? As Oliver (1999) noted, intentions are frequently not fulfilled, thus we expected that past behavior would predict current behavior at least to some extent. In addition, most athletics departments assume a season ticket renewal rate of around $70 \%$ or more, showing past behavior predicting future behavior. Therefore, to have less than 3\% of the variance of current behavior explained by past behavior was surprising. Obviously, it could be due to the sample, but considering that Yoshida et al. (2015) found similar results, it seems that intentions may fully mediate this relationship. A similar mediated model should be tested on a new sample to see if this can be replicated.

Implications for organizations. The implications for organizations are straightforward. Sports marketers and administrators need to take into account both the impact of role identity as a fan of the team and attendance intentions, not solely prior attendance behavior. Obviously, if the mediated relationships are accurate, 
sports marketers need to be aware of the mediating effects primarily of intentions, but also to some extent need to also be aware of team-fan role identity. Including only some of these variables in market research and not others may give dramatically different results. Second, marketers need to be aware of the differences between attending the game and just supporting the team in general. On the face of it, this is a readily apparent assumption. Fans can certainly support the team and not attend; and spectators can attend, but not support the team in other ways (e.g., attending for business purposes or because other family members do). In sum, sports marketers need to be aware of the interplay among these variables and take into account each of them when trying to determine future attendance behavior and support for the team.

Specifically though, collegiate administrators, especially at small colleges, need to understand that students that go to games during the prior year, will increase their fandom, will intend to go to more games in the future, and will follow through by going to more games. Thus, administrators need to identify those students and encourage them to be ambassadors for the team, advocate for the team on social media, and talk up the team to their friends and family, because these students are the most loyal cognitively, conatively, and behaviorally. These are the advocates for the team and thus the most likely to be able to convince other students to attend.

Study limitations. We have noted some of the limitations already, but as with most studies, replication is critical, especially across fans of a variety of different teams, leagues, and levels. Second, as with most longitudinal research, we had substantial dropout. We lost about $60 \%$ of the original sample, so future research should start with a considerably larger sample. Third, team success was not measured and certainly could have an impact on all of the variables. Or perhaps even better, expectancy (dis)confirmation could be included. Future research should include that variable, if possible. Fourth, the specific path coefficients are only representative of this particular sample and because we tracked only one team at one university, the coefficients are not generalizable to other data sets.

Suggestions for future research. We have already made some suggestions for future research, but we think the most important is to test the potential mediated relationships and determine if they replicate. We expect that they will since they were apparent in Yoshida et al.'s (2015) research as well. In addition, tracking people across multiple seasons would be extremely interesting as well.

In sum, we have extended the literature considerably through this research, mainly by doing a longitudinal study that incorporated team-fan role identity (TII), conative loyalty, and behavioral loyalty. We 
have shown relationships that have not been tested before and explained more variance in some variables than any previous research. However, as noted above, we may have created as many questions as we answered. 


\section{References}

Agyemang, K., Singer, J. N., \& DeLorme, J. (2010). An exploratory study of black male college athletes' perceptions on race and athlete activism. International Review for the Sociology of Sport, 45(4), 419-435.

Ajzen, I. (1991). The theory of planned behavior. Organizational Behavior and Human Decision Processes, 50, 179-211.

Ajzen, I., \& Madden, T. J. (1986). Prediction of goal-directed behavior: Attitudes, intentions, and perceived behavioral control. Journal of Experimental Social Psychology, 22, 453-474.

Baade, R. A. \& Tiehen, L. J. (1990). An analysis of Major League Baseball attendance, 1969 -1987. Journal of Sport and Social Issues, 14, 14-32.

Bee, C. \& Havitz, M. (2010). Exploring the relationship between involvement, fan attraction, psychological commitment and behavioral loyalty in a spots spectator context. International Journal of Sports Marketing \& Sponsorship, 11, 140-157.

Bodet, G. \& Bernache-Assolant, I. (2011). Consumer loyalty in sport spectatorship services: The relationships with consumer satisfaction and team identification. Psychology \& Marketing, 28, 781-802.

Bowl Subdivision Membership. (2016).

Football Bowl Subdivision Membership Requirements. https://www.ncaa.org/sites/default/
files/Football $\% 20$ Bowl $\% 20$ Subqa $\% 2$ 012\%208\%2014.pdf

Dick, A. S. \& Basu, K. (1994). Customer loyalty: Toward an integrated conceptual framework. Journal of the Academy of Marketing Science, 22, 99113.

Ervin, L. H., \& Stryker, S. (2001). Theorizing the relationship between self-esteem and identity. In T. J. Owens, S. Stryker \& Goodman, N. (Eds.), Extending self-esteem theory and research: Sociological and psychological currents (pp. 29-55). Cambridge: University Press.

Fink, J. S., Trail, G. T., \& Anderson, D. F. (2002). An examination of team identification: Which motives are most salient to its existence? International Sports Journal. 6(Summer), 195-207.

Gau, L., Wann, D., \& James, J. D. (2010). Examining relations of entertainment with social interaction motives and team identification. Perceptual and Motor Skills, 111, 576-588.

Gray, G. T., \& Wert- Gray, S. (2012).

Customer retention in sports organization marketing: examining the impact of team identification and satisfaction with team performance. International Journal of Consumer Studies, 36, 275-281

Greenstein, T. N. \& Marcum, J. P. (1981). Factors affecting attendance of major league baseball: Team performance. Review of Sport and Leisure, 6(2), 21-34. 
Harrolle, M. G., Trail, G. T., Rodríguez, A., \& Jordan, J. S. (2010). Conative loyalty of Latino and Non-Latino professional baseball fans. Journal of Sport Management, 24, 456-471.

Heere, B., Walker, M. Yoshida, M., Ko, Y. J., Jordan, J. S., \& James, J. D. (2011). Brand community development through associated communities: Grounding community measurement within social identity theory. Journal of Marketing Theory and Practice, 19, 407422.

Hobson, W., \& Rich, S. (2015). Playing in the red. The Washington Post. Retrieved on August 5th, 2016 from http://www.washingtonpost.com/sf /sports/wp/2015/11/23/runningup-the-bills/.

Hu, L., \& Bentler, P. M. (1999). Cutoff criteria for fit indexes in covariance structure analysis: Conventional criteria versus new alternatives. Structural Equation Modeling, 6, 1-55.

James, J. D. \& Trail, G.T. (2008). The relevance of team identification to sport consumption behavior intentions. International Journal of Sport Management, 9, 427-440.

Kim, Y. K. \& Trail, G. T. (2010).

Constraints and motivators: A new model to explain consumer behavior. Journal of Sport Management, 24, 190 210.

Kim, Y. K., Trail, G. T., \& Magnusen, M. J. (2013). Transition from motivation to behavior: Examining the moderating role of identification on the relationship between motives and attendance. International Journal of Sport Marketing and Sponsorship, 14, 190-211. Kwon, H. H., Trail, G. T., \& Anderson, D. F. (2005). Are multiple points of attachment necessary to predict cognitive, affective, and conative, or behavioral loyalty? Sport Management Review, 8, 255-270.

Laverie, D. L., \& Arnett, D. B. (2000).

Factors affecting fan attendance: The influence of identity salience and satisfaction. Journal of Leisure Research, 32, 225-246.

Lock, D., Funk, D. C., Doyle, J. P., \& McDonald, H. (2014). Examining the longitudinal structure, stability, and dimensional interrelationships of team identification. Journal of Sport Management, 28, 119-135.

Mael, F., \& Ashforth, B. E. (1992). Alumni and their alma mater: A partial test of the reformulated model of organizational identification. Journal of Organizational Behavior, 13, 103-123.

Matsuoka, H., Chelladurai, P., \& Harada, M. (2003). Direct and interaction effects of team identification and satisfaction on intention to attend games. Sport Marketing Quarterly, 12, 244-253. McDonald, H., Karg, A. J., \& Leckie, C. (2014). Predicting which season ticket holders will renew and which will not. European Sport Management Quarterly, 14, 503-520. 
NCAA. (2016). 2015 National College

Football Attendance.

http:// fs.ncaa.org/Docs/stats/footb all_records/Attendance/2015.pdf

Oliver, R. L. (1997). Satisfaction: A behavioral perspective on the consumer. New York: McGraw-Hill Companies, Inc.

Oliver, R. L. (1999). Whence consumer loyalty? Journal of Marketing, 63, Special Issue, 33-44.

Shapiro, S., Ridinger, L., \& Trail, G. T. (2013). An analysis of multiple spectator consumption behaviors, identification, and future behavioral intentions within the context of a new college football program. Journal of Sport Management, 27, 130-145.

Stets, J. E., \& Burke, P. J. (2000). Identity theory and social identity theory. Social Psychology Quarterly, 63, 224-237.

Stryker, S., \& Burke, P. J. (2000). The past, present, and future of an identity theory. Social Psychology Quarterly, 63, 284-297.

Trail, G. T., Anderson, D. F., \& Fink, J. S. (2000). A theoretical model of sport spectator consumption behavior. International Journal of Sport Management, 1, 154-180.

Trail, G. T., Anderson, D. F., \& Fink, J. S. (2005). Consumer satisfaction and identity theory: A model of sport spectator conative loyalty. Sport Marketing Quarterly, 14, 98-112.

Trail, G. T., Fink, J. S., \& Anderson, D. F. (2003). Sport spectator consumption behavior. Sport Marketing Quarterly, 12, 8-17.

Trail, G. T., \& James, J. D. (2001). The Motivation Scale for Sport Consumption: Assessment of the scale's psychometric properties. Journal of Sport Behavior, 24(1), 108127.

Trail, G. T., \& James, J. D. (2015). Sport Consumer Behavior (2 ${ }^{\text {nd }}$ ed.). Seattle, WA: Sport Consumer Research Consultants LLC.

Wang, R. T., Zhang, J. J., \& Tsuji, Y. (2011). Examining fan motives and loyalty for the Chinese Professional Baseball League of Taiwan. Sport Management Review, 14, 347-360.

Wu, S. H., Tsai, C. Y. D., \& Hung, C. C. (2012). Toward team or player? How trust, vicarious achievement motive, and identification affect fan loyalty. Journal of Sport Management, 26, 177191.

Yoshida, M., Gordon, B., Nakazawa, M., \& Biscaia, R. (2014). Conceptualization and measurement of fan engagement: Empirical evidence from a professional sport context. Journal of Sport Management, 28, 399-417.

Yoshida, M., Heere, B., \& Gordon, B. (2014). Predicting behavioral loyalty through community: Why other fans are more important than our own intentions, our satisfaction, and the team itself. Journal of Sport Management, 29, 318-333. 
Zhang, J. J., Pennington-Gray, L.,

Connaughton, D. P., Braunstein, J.

R., Ellis, M. H., Lam, E. T. C., \&

Williamson, D. (2003).

Understanding women's professional

basketball game spectators:

sociodemographics, game

consumption, and entertainment

options. Sport Marketing Quarterly, 12,

228-243. 


\section{Tables}

Table 1

Factor Loadings ( $\beta$ ), Confidence Intervals (CI), Standard Errors (SE), Construct Reliability (CR) and Average Variance Explained (AVE) Values

\begin{tabular}{|c|c|c|c|c|c|}
\hline Factor and Item & $\beta$ & $\mathrm{CI}$ & $\mathrm{SE}$ & $C R$ & AVE \\
\hline Preseason Team Identification & & & & .88 & .712 \\
\hline $\begin{array}{l}\text { I consider myself to be a "real" fan } \\
\text { of the team }\end{array}$ & .856 & $.810-.901$ & .027 & & \\
\hline $\begin{array}{l}\text { I would experience a loss if I had } \\
\text { to stop being a fan of the team }\end{array}$ & .781 & $.722-.839$ & .036 & & \\
\hline $\begin{array}{l}\text { Being a fan of the team is very } \\
\text { important to me }\end{array}$ & .891 & $.851-.930$ & .024 & & \\
\hline Postseason Team Identification & & & & .88 & .706 \\
\hline $\begin{array}{l}\text { I consider myself to be a "real" fan } \\
\text { of the team }\end{array}$ & .848 & $.803-.893$ & .028 & & \\
\hline $\begin{array}{l}\text { I would experience a loss if I had } \\
\text { to stop being a fan of the team }\end{array}$ & .762 & $.700-.823$ & .037 & & \\
\hline $\begin{array}{l}\text { Being a fan of the team is very } \\
\text { important to me }\end{array}$ & .905 & $.869-.941$ & .022 & & \\
\hline \multicolumn{6}{|l|}{$\begin{array}{l}\text { How many (team name) home } \\
\text { football games did you go to last } \\
\text { year? }\end{array}$} \\
\hline \multicolumn{6}{|l|}{$\begin{array}{l}\text { How many of the seven (team name) } \\
\text { home football games do you plan } \\
\text { on attending this year? }\end{array}$} \\
\hline \multicolumn{6}{|l|}{$\begin{array}{l}\text { How many home (team name) } \\
\text { football games did you attend this } \\
\text { season? }\end{array}$} \\
\hline I am likely to attend future games. & & & & & \\
\hline $\begin{array}{l}\text { I am likely to support the (team name) } \\
\text { football team in the future. }\end{array}$ & & & & & \\
\hline
\end{tabular}


Table 2

Correlations from the CFA, Average V ariance Explained (AVE) Values, Squared Correlations, Means, and Standard Deviations

\begin{tabular}{llllllll}
\hline Variables & 1 & 2 & 3 & 4 & 5 & 6 & 7 \\
\hline 1. Pre Role Identity & .712 & .667 & .191 & .206 & .144 & .268 & .277 \\
2. Post Role Identity & .817 & .706 & .177 & .235 & .233 & .375 & .377 \\
3. PastAttendance & .438 & .421 & ---- & .404 & .338 & .183 & .148 \\
4. \#gamesIntending & .454 & .485 & .636 & --- & .624 & .325 & .219 \\
5. PresentAttendance & .380 & .483 & .581 & .790 & --- & .339 & .236 \\
6. LikelihoodAttending & .518 & .612 & .428 & .570 & .582 & --- & .613 \\
7. LikelihoodSupport & .526 & .614 & .385 & .468 & .486 & .783 &.-- \\
\hdashline Mean & 4.73 & 4.01 & 3.59 & 5.07 & 4.32 & 5.79 & 5.95 \\
Standard Deviation & 1.44 & 1.23 & 2.67 & 2.39 & 2.59 & 1.43 & 1.20
\end{tabular}

Note: Correlations below the diagonal. AVE values in bold on the diagonal. Squared correlations above the diagonal. 
Table 3

Path Coefficients and Fit Indices across Both Models

Model A Model B

Path

Preseason Role Identity (Time 1)

H7 (Supported): Prior Season Attendance (T1) $\rightarrow$ \# of Games $\quad .541 \quad .541$

Intending to Attend (T1)

H9 (Not supported): Prior Season Attendance (T1) $\rightarrow$ Self- $\quad .131 \quad .131$

reported Season Attendance (T2)

H1 (Supported): Preseason Role Identity (T1) $\rightarrow$ \# of Games $\quad .219 \quad .218$

Intending to Attend (T1)

H5 (Not supported): Preseason Role Identity (T1) $\rightarrow$ Self- $\quad .004 \quad .005$

reported Season Attendance (T2)

H9 (Supported): Preseason Role Identity (T1) $\rightarrow$ Postseason $\quad .743 \quad .743$

Role Identity (T2)

H8 (Supported): \# of Games Intending to Attend (T1) $\rightarrow$ Self- $\quad .705 \quad .705$

reported Season Attendance (T2)

H4 (Supported): Self-reported Season Attendance (T2) $\rightarrow \quad .202 \quad .202$

Postseason Role Identity (T2)

H7 (Supported) Self-reported Season Att. (T2) $\rightarrow$ End-of-Year $\quad .370$

Attend Intentions (T3)

H7 (Supported) Self-rep. Seas. Att. (T2) $\rightarrow$ End-of-Year Intent

to Support Team (T3)

H2 (Supported) Postseason Role ID (T2) $\rightarrow$ End-of-Year $\quad .438$

Attendance Intentions (T3)

H2 (Supported) Postseason Role ID (T2) $\rightarrow$ End-of-Year

.502

Intent to Support Team (T3)

\begin{tabular}{llcc}
\hline $\mathrm{R}^{2}$ & Preseason Role Identity & $18.9 \%$ & $18.8 \%$ \\
& \# of Games Intending to Attend & $44.3 \%$ & $44.2 \%$ \\
& Self-reported Season Attendance & $63.5 \%$ & $63.5 \%$ \\
& Postseason Role Identity & $70.7 \%$ & $70.7 \%$ \\
& End-of-Year Likelihood to Attend Future Games & $48.5 \%$ & \\
& End-of-Year Likelihood to Support Team in & & $42.9 \%$ \\
& Future & & \\
\hline Model Fit & RMSEA & .066 & .060 \\
& $\mathrm{X}^{2} / d f$ & 1.73 & 1.59 \\
\hline
\end{tabular}

Note: H1-H9 = Hypothesis 1-9; T1 = Time 1, T2 = Time 2, T3 = Time 3

Journal of Amateur Sport $\quad$ Volume Three, Issue One Trail et al., 2017 
Figure 1

Competing Models of Attendance and Intentions to Support the Team

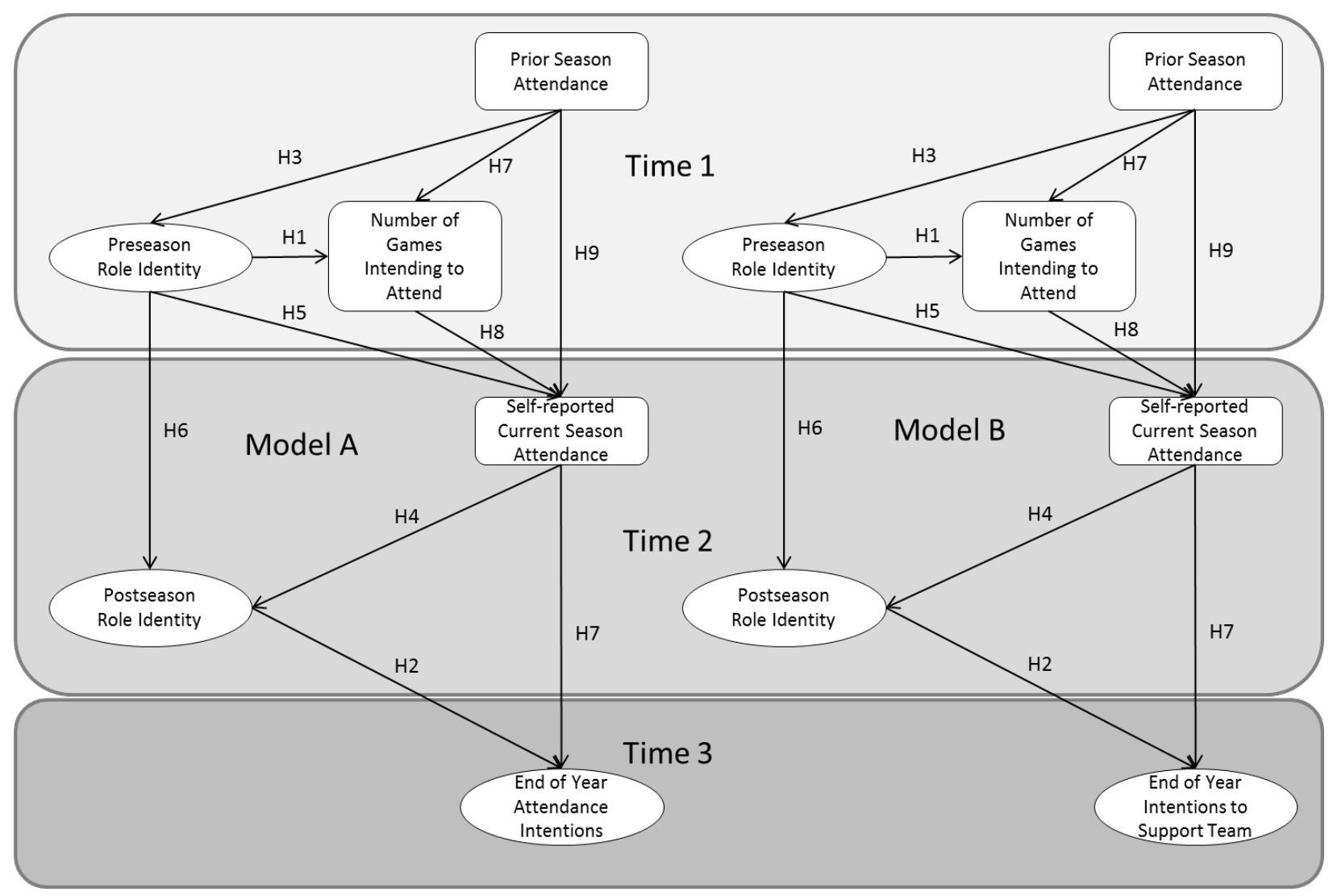

